\title{
LITERASI MATEMATIKA SISWA DALAM MENYELESAIKAN SOAL PROGRAMME FOR INTERNATIONAL STUDENT ASSESSMENT (PISA)
}

\author{
Janet Trineke Manoy ${ }^{1}$, Marinda Rosita Sari \\ ${ }^{1,2}$ Department of Mathematics, Universitas Negeri Surabaya, Pascasarjana, Universitas Pattimura \\ Jl. Ketintang Surabaya, East Java, Indonesia \\ e-mail: 1 janetmanoy@unesa.ac.id; ${ }^{2}$ mrositasari@gmail.com
}

\begin{abstract}
Abstrak
Literasi matematika adalah kemampuan seseorang untuk merumuskan, menerapkan, dan menafsirkan matematika dalam berbagai konteks. Penelitian ini bertujuan untuk mendeskripsikan literasi matematika siswa kelas X SMA dalam menyelesaikan soal PISA. Pengumpulan data dilakukan menggunakan tes, dan wawancara. 2 soal level 4 dan level 6 diberikan kepada siswa. Analisis data berdasarkan indikator proses matematika PISA yaitu merumuskan, menerapkan, dan menafsirkan. Hasil penelitian menunjukkan bahwa: Pada proses merumuskan, siswa menyebutkan informasi-informasi penting dalam soal, bagaimana menyelesaikannya dan konsep apa yang akan digunakan, serta apa yang diketahui dan ditanyakan dalam soal. Pada proses menerapkan siswa merancang dan menerapkan strategi sesuai informasi-informasi yang telah dibuatnya, menggambar objek yang diperlukan sesuai soal yang diberikan. Pada proses menafsirkan, siswa menjelaskan alasan mengapa kesimpulan yang diperolehnya sesuai dengan konteks permasalahan yang diberikan.
\end{abstract}

Kata Kunci: Literasi Matematika, Soal Matematika PISA

\section{STUDENT MATHEMATICS LITERACY IN SOLVING PROGRAMME FOR INTERNATIONAL STUDENT ASSESSMENT (PISA) PROBLEMS}

\begin{abstract}
Mathematical literacy is a person'a ability to formula, apple, and interpret mathematics in various contenxts. This study aims to describe the mathematical literacy of class $\mathrm{X}$ high school students in solving PISA questions. Date collection wa carried out using tests and interviews. 2 questions level 4dan level 6 are given to students. Date analysis is based on PISA mathematical process indicators namely formulating, applying, and interpreting. The results showed that: in the process of formulating, students mentioned important information in the problem, how to slove it and what concepts would be used, as well as what was know and asked in the problem. In the process of applying students to design and implement strategies according to the information they have made, draw the required objects according to the questions given. In the process of interpreting, students explain the reasons why the conclusions they get are in accordance with the context of the problem given.
\end{abstract}

Keywords: Mathematics Literacy, PISA Mathematics Problems

\section{Pendahuluan}

Salah satu skala penilaian internasional yaitu PISA (Programme For International Student Assessment), bertujuan untuk menilai kemampuan membaca, matematika, dan IPA siswa yang disebut literasi, dikhususkan bagi siswa yang berusia 15 tahunan atau yang mendekati tahap akhir evaluasi pendidikan secara berkala (OECD, 2013a; 2013b; dan 2016). PISA tidak hanya menilai kemampuan siswa, tetapi juga penerapan pengetahuan dalam situasi yang berbeda. Menurut Organisation for Economic Co-operation and Development (OECD), hasil studi PISA merupakan pembanding dalam merumuskan kebijakan untuk meningkatkan mutu pendidikan (OECD, 2016). United Nations Educational, Scientific and Cultural Organization (UNESCO) mendeklarasikan literasi sebagai hak asasasi 
manusia. "Literacy is not an end in itself. It is a fundamental human right.",(OECD, 2013a) dan salah satu deklarasi ini mengutarakan tentang literasi sebagai bagian penting dari pendidikan, sehingga Kementrian Pendidikan dan Kebudayaan (Kemendikbud) ikut mencetuskan Gerakan Literasi Sekolah (GLS) pada tahun 2015, sebagai salah satu upaya untuk meningkatkan mutu pendidikan. Pelaksanaan GLS dituliskan dalam Peraturan Menteri Pendidikan dan Kebudayaan Nomor 23 Tahun 2015, dimana GLS merupakan program berkelanjutan untuk menjadikan sekolah sebagai organisasi pembelajaran yang warganya literat. Literat merupakan sebutan bagi seseorang yang mampu berliterasi sedangkan literasi adalah kemampuan seseorang untuk merumuskan, menerapkan, dan menafsirkan matematika dalam berbagai konteks dengan menggunakan konsep, prosedur, fakta, dan alat matematika agar dapat mendiskripsikan, menjelaskan, dan memprediksi fenomena (OECD; Steen et al, 2013; 2007). Kenyataan menunjukkan bahwa siswa Indonesia mengalami kesulitan pada proses merumuskan masalah dalam kehidupan sehari-hari ke dalam model matematika (Edo dkk; Jupri dkk, 2013: 2014)

Kerangka kerja PISA dalam mengukur literasi matematika dibedakan dalam tiga aspek, yaitu konten, konteks, dan kognitif. Aspek konten atau materi pada PISA terdiri dari konten quantity, uncertainty and data, change and relationship, dan space and shape. Aspek konteks terdiri dari konteks personal, societal, occupational, dan scientific. Sementara aspek kognitif terdiri atas enam tingkatan mulai tingkat paling rendah sampai tingkat tertinggi pengetahuan (OECD, 2016). Pada penelitian ini peneliti mengadaptasi soal PISA konten space and shape pada level 4 dan level 6 karena hasil terendah pencapaian siswa Indonesia pada konten space and shape dan berdasarkan hasil Penilaian PISA 2012 hampir seluruh siswa Indonesia mampu mencapai level 3 sehingga peneliti ingin mengetahui bagaimana literasi matematika siswa jika level soalnya dinaikkan dari level tertinggi yang mampu dicapai siswa.
Tujuan penelitian ini yaitu untuk mendeskripsikan literasi matematika siswa kelas X SMA dalam menyelesaikan soal PISA

\section{Metode Penelitian}

Jenis penelitian ini merupakan penelitian kualitatif, yaitu mengkaji fenomena dalam keadaan seadanya dan berusaha mendeskripsi fenomena tersebut. Subjek yang dipilih yaitu seorang siswa SMA kelas X dengan kriteria: dapat mengkomunikasikan ide/pendapat atau jalan pikirannya secara lisan dan tertulis dengan sederhana dan jelas. Subjek yang memenuhi kriteria tersebut dipilih dari keseluruhan calon subjek, kemudian dilakukan wawancara berbasis tugas. Pengumpulan data menggunakan metode tes dan wawancara, instrumen yang digunakan yaitu tes literasi matematika PISA, dan pedoman wawancara. Tes literasi matematika PISA menyajikan dua masalah matematika dan hasil wawancara dianalisis menggunakan 5 langkah yaitu: a) memilih dan mengidentifikasi data; b) menulis kumpulan data; c) mengecek keabsahan data; d) menetapkan data; dan d) menarik kesimpulan dari data yang sudah dikumpulkan.

\section{Hasil dan Pembahasan}

\subsection{Hasil}

Subjek penelitian menyelesaikan 2 soal matematika PISA konten space and shape

\subsubsection{Literasi Matematika PISA Subjek Untuk Soal Nomor 1}

Berdasarkan Gambar 1, subjek menyelesaikan soal nomor 1 menggunakan rumus luas lingkaran yaitu $\pi r^{2}$, kemudian memasukan nilai $\pi=3,14$ dan $r=100$ ke dalam rumus dan diperoleh luas lingkarannya yaitu $31400 \mathrm{~cm}^{2}$. kemudian membagi luas tersebut dengan 3, sehingga diperoleh luas daerah yang dibatasi oleh dua sayap pintu yaitu $10466,6 \mathrm{~cm}^{2}$. 


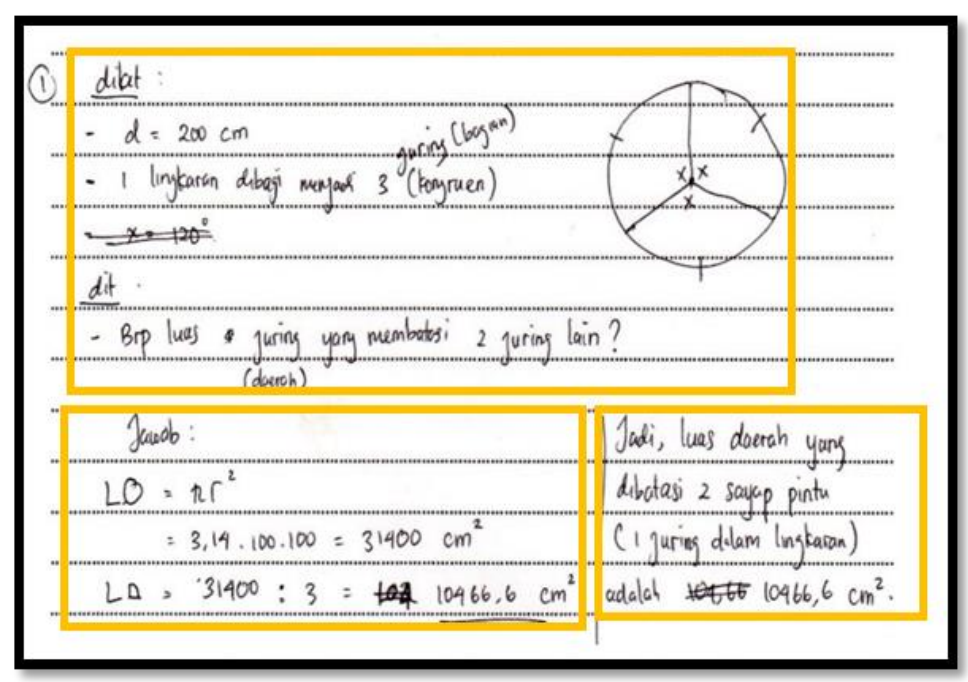

Gambar 1. Hasil tes literasi matematika pisa nomor 1

Hasil analisis indikator literasi matematika yang dilakukan subjek dalam menyelesaikan soal tes literasi PISA nomor 1 sebagai berikut

\subsubsection{Proses Merumuskan (Formulate)}

Pada proses merumuskan, Subjek menyebutkan informasi penting berkaitan dengan soal yang akan diselesaikan yaitu: pintu putar/revolving door berbentuk lingkaran, diameter pintu, dan ruang pintu putar yang dibagi ke dalam 3 bagian sama besar. Cara menyelesaikannya dengan menghitung diameter dan luas daerah yang dibatasi oleh 3 sayap. Subjek memperhatikan informasi yang sudah tertulis pada soal dan menyebutkan apa yang diketahui dan ditanyakan sehingga lebih mudah untuk diselesaikan. Subjek menambahkan gambar agar lebih memahami informasi yang diketahuinya.

Dari uraian tersebut, dapat diketahui bahwa pada proses merumuskan Subjek dapat mengidentifikasi aspek - aspek matematika yang digunakan dalam menyelesaikan masalah dan menyebutkan apa yang diketahui dan ditanyakan pada soal.

\subsubsection{Proses Menerapkan (Employ)}

Pada proses menerapkan, Subjek merancang strategi untuk menemukan solusi dengan menyebutkan pengetahuan yang akan digunakan untuk menjawab soal. Subjek mengemukakan bahwa soal tersebut dapat diselesaikan dengan menggunakan rumus luas lingkaran, sehingga dapat menemukan luas daerah yang dibatasi oleh dua sayap pintu, Subjek merancang strategi untuk terlebih dahulu mencari luas lingkaran dan kemudian membaginya dengan
3. Langkah selanjutnya Subjek menerapkan konsep matematika yang diperlukan yaitu $\pi r^{2}$ untuk menghitung luas lingkarannya dengan memasukkan nilai $\pi=3,14$ dan $r=100$, setelah itu luas lingkaran yang diperoleh dibagi 3 dan hasilnya $10466,6 \mathrm{~cm}^{2}$

Dari uraian tersebut, dapat diketahui bahwa pada proses ini Subjek menerapkan strategi sesuai rancangan yang dibuatdengan menggunakan fakta, aturan, dan konsep matematika yang diperlukan.

\subsubsection{Proses Menafsirkan (Interpret)}

Pada proses menafsirkan, Subjek memperhatikan kembali hasil penyelesaian yang dibuat dan menafsirkannya untuk dipakai dalam konteks permasalahan dunia nyata dengan membuat kesimpulan dan menjelaskan hubungan hasil yang didapatkan dengan soal yang diberikan yaitu luas daerah yang dibatasi oleh dua sayap pintu yaitu $10466,6 \mathrm{~cm}^{2}$. Subjek juga menjelaskan alasan mengapa hasil atau kesimpulan yang diperoleh sesuai atau tidak sesuai dengan konteks permasalahan yang diberikan dengan mengemukakan bahwa hasil perhitungan yang diperolehnya sudah benar. Subjek meyakini hasil perhitungannya benar dengan cara mengecek kembali hasil perhitungannya. Selain itu Subjek juga mengemukakan bahwa jawaban yang diperolehnya masuk akal dengan memberikan penjelasan mengapa jawaban yang diperolehnya masuk akal.

Dari uraian tersebut, dapat diketahui bahwa pada proses ini subjek dapat menafsirkan kembali hasil penyelesaian yang diperoleh ke 
dalam konteks permasalahan dunia nyata dan menjelaskan alasan mengapa hasil atau kesimpulan sesuai atau tidak sesuai dengan konteks permasalahan yang diberikan.

\subsubsection{Literasi Matematika PISA subjek untuk soal nomor 2}

Berdasarkan Gambar 2, Subjek menyelesaikan soal nomor 2 dengan mencari keliling lingkaran dan diperoleh $628 \mathrm{~cm}$, kemudian mencari panjang busur salah satu juring dengan cara membagi keliling lingkaran dengan 3, dan diperoleh 209,3 cm. Langkah selanjutnya, menemukan panjang busur maksimum pintu yang harus dibuat yaitu dengan membagi panjang busur salah satu juring dengan 2 dan diperoleh $104,65 \mathrm{~cm}$. Subjek menyimpulkan bahwa pintu yang harus dibuat memiliki panjang busur $104,65 \mathrm{~cm}$.

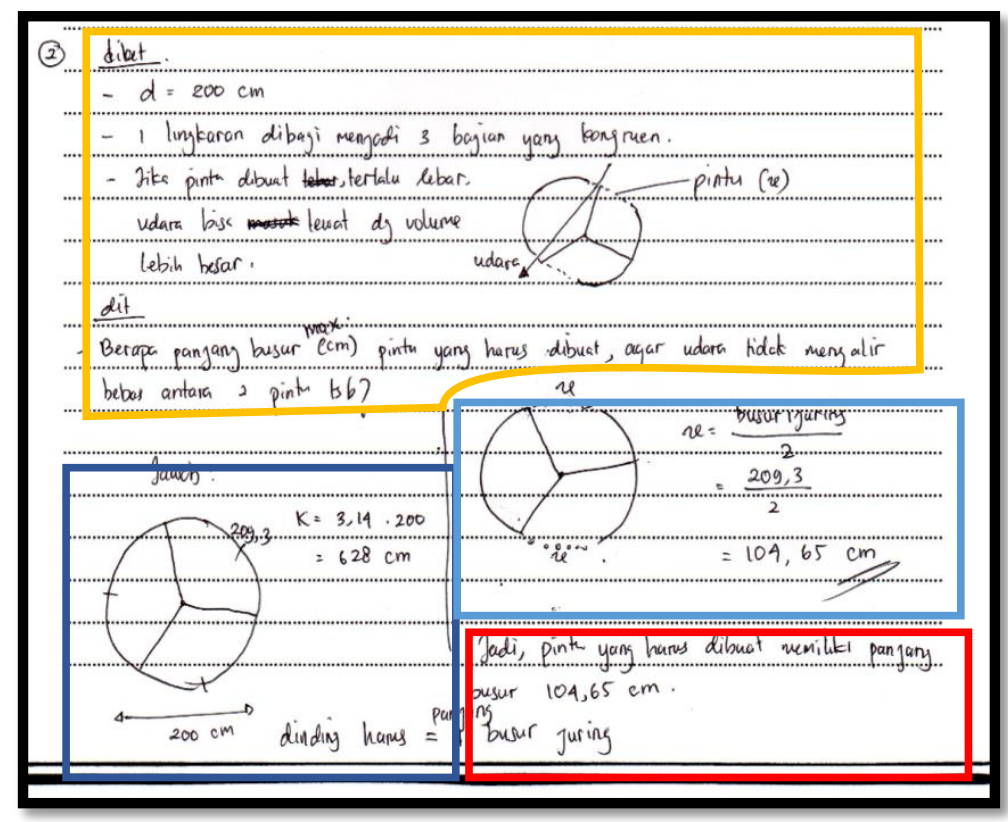

Gambar 2. Hasil tes literasi matematika pisa nomor 2

Hasil analisis indikator literasi matematika yang dilakukan subjek dalam menyelesaikan soal tes literasi PISA nomor 2 sebagai berikut.

\subsubsection{Proses Merumuskan (Formulate)}

Pada proses merumuskan, Subjek menyebutkan informasi penting yang berkaitan dengan soal yang akan diselesaikan yaitu: diameter pintu putar, lingkaran yang dibagi menjadi 3 bagian sama besar, pembuatan pintu yang terlalu lebar yang dapat membuat udara masuk lewat rongga atau celah yang terbuka, dan panjang pintu masuk dan pintu keluar yang sama. Cara menyelesaikannya dengan menentukan panjang pintu yang pas/maksimum agar udara tidak bisa masuk lewat rongga-rongga yang terbuka. Langkah selanjutnya Subjek menyebutkan apa yang diketahui dan yang ditanyakan pada soal. Subjek menambahkan gambar untuk lebih memahami informasi yang diketahui pada soal dan memudahkan dalam pengerjaannya.

Dari uraian di atas, dapat diketahui bahwa pada proses merumuskan Subjek dapat mengidentifikasi aspek-aspek matematika yang akan digunakan dalam menyelesaikan masalah dan menyebutkan informasi-informasi penting dalam soal dan bagaimana menyelesaikannya serta dapat menyebutkan apa yang diketahui dan ditanyakan pada soal.

\subsubsection{Proses Menerapkan (Employ)}

Pada proses menerapkan, Subjek merancang strategi untuk menemukan solusi dengan menyebutkan pengetahuan yang akan digunakan untuk menjawab soal. Subjek mengemukakan bahwa soal tersebut dapat diselesaikan dengan menentukan keliling lingkaran terlebih dahulu, kemudian menentukan panjang busur salah satu juring lingkaran, setelah itu menghitung panjang busur maksimal pintu yang harus dibuat. Rumus yang digunakan yaitu rumus keliling dan panjang busur lingkaran untuk menentukan panjang pintu yang harus dibuat. Subjek menuliskan langkah-langkah yang dilakukan dan menggambar objek yang diperlukan.

Dari uraian tersebut, dapat diketahui bahwa pada proses ini Subjek menerapkan 
strategi sesuai rancangan yang dibuat dengan menggunakan fakta, aturan, dan konsep matematika yang diperlukan.

\subsubsection{Proses Menafsirkan (Interpret)}

Pada proses menafsirkan, Subjek memperhatikan kembali hasil penyelesaian yang dibuat dan menafsirkannya untuk dipakai dalam konteks permasalahan dunia nyata dengan membuat kesimpulan dan menjelaskan hubungan hasil yang didapatkan dengan soal yang diberikan yaitu agar udara tidak bisa masuk melewati rongga atau celah berarti panjang pintu masuk yang dibuat panjangnya harus sama dengan panjang busur satu juring lingkaran. Jadi panjang pintu maksimum yang harus dibuat agar udara tidak bisa masuk dari pintu masuk ke pintu keluar yaitu 104,65 cm. Subjek juga menjelaskan alasan mengapa hasil atau kesimpulan yang diperoleh sesuai dan sudah benar juga masuk akal karena sudah dihitung kembali dan mengecek hasilnya.

Dari uraian tersebut, dapat diketahui bahwa pada proses ini Subjek dapat menafsirkan kembali hasil penyelesaian yang diperoleh ke dalam konteks permasalahan dunia nyata dan menjelaskan alasan mengapa hasil atau kesimpulan sesuai atau tidak sesuai dengan konteks permasalahan yang diberikan.

\subsection{Pembahasan}

Berdasarkan hasil dan analisis data tes literasi matematika PISA, diketahui bahwa pada proses merumuskan (formulate), subjek mengidentifikasi aspek-aspek matematika yang digunakan dalam menyelesaikan masalah dengan beberapa cara yaitu (1) menyebutkan informasiinformasi penting yang ada pada soal; (2) menceritakan kembali soal dengan menggunakan bahasanya sendiri; (3) menjelaskan materi matematika yang digunakan untuk menyelesaikan soal. Subjek hanya menyebutkan informasiinformasi penting yang ada pada soal saja, padahal ada informasi penting yang tidak tertulis pada soal dan informasi tersebut dapat diketahui dari informasi-informasi yang tertulis pada soal jika subjek memahami soal yang diberikan dengan baik. Subjek juga menuliskan apa yang diketahui dan ditanyakan pada soal dengan cara yaitu (1) menuliskan informasi-informasi apa saja yang diketahui dan ditanyakan pada soal di lembar jawaban; (2) menggambar objek dari informasi-informasi yang diketahui pada soal. Pada proses menerapkan (employ), subjek merancang dan menerapkan strategi untuk menemukan solusi matematika dengan menyebutkan konsep matematika yang digunakannya dan menjelaskan langkah-langkah yang dilakukan dalam menyelesaikan soal. Subjek menerapkan strategi yang telah dirancangnya dengan menerapkan fakta, aturan, dan konsep matematika yang diperlukan selama proses menemukan solusi. Subjek menulis langkahlangkah yang dilakukan dan menggambar objek yang diperlukan untuk menyelesaikan masalah. Tetapi subjek tidak menuliskan rumus yang digunakan dan langkah-langkah yang dilakukan dengan lengkap dan runtut melainkan menggantinya dengan menggambar beberapa objek untuk menjelaskan langkah-langkah yang dilakukannya.

Selanjutnya, pada proses menafsirkan (interpret), subjek menuliskan kesimpulan dari hasil pekerjaan yang diperolehnya di lembar jawaban dan menjelaskan hubungan hasil yang didapatkan dengan soal permasalahan dunia nyata yang diberikan. Selain itu subjek mengemukakan bahwa hasil perhitungan yang diperolehnya sudah benar dan meyakini hasil perhitungannya benar dengan cara mengecek kembali hasil perhitungannya. Subjek juga mengemukakan bahwa jawaban yang diperolehnya masuk akal dengan memberikan penjelasan namun penjelasan yang diberikan kurang dapat menjelaskan dengan baik mengapa jawaban yang diperoleh masuk akal atau tidak dengan soal yang diberikan.

\section{Kesimpulan}

Berdasarkan hasil penelitian maka diperoleh kesimpulan yaitu: Pada proses merumuskan, subjek menyebutkan informasiinformasi penting dalam soal, bagaimana menyelesaikannya dan konsep apa yang akan digunakan, serta apa yang diketahui dan ditanyakan dalam soal. Pada proses menerapkan subjek merancang dan menerapkan strategi sesuai informasi-informasi yang telah dibuatnya, menggambar objek yang diperlukan sesuai soal yang diberikan. Pada proses menafsirkan, subjek menjelaskan alasan mengapa kesimpulan yang diperolehnya sesuai dengan konteks permasalahan yang diberikan.

\section{Daftar Pustaka}

Edo, S. I., Hartono, Y., \& Putri, R. I. 2013. "Investigating Secondary School Student's Difficulties in Modelling Problem PISA-Model Level 5 and 6". Journal on Mathematics Education (IndoMS-JME). Vol. 4 (1): hal 4158. 
Jupri, A., dkk. 2014. "Difficulties in Initial Algebra Learning in Indonesia". Mathematics Education Research Journal: pp 1-28

Kemendikbud. 2014. Peraturan Menteri Pendidikan dan Kebudayaan Nomor 59 tentang Kurikulum 2013 Sekolah Menengah Atas/Madrasah Aliyah. Jakarta: Kemendikbud.

Mahdiansyah \& Rahmawati. 2014. "Literasi Matematika Siswa Pendidikan Menengah: Analisis Menggunakan Desain Tes Internasional Dengan Konteks Indonesia”. Jurnal Pendidikan Dan Kebudayaan. Vol. 20 (4): hal 452-469.

UNESCO. 1975. International Symposium for Literacy, Paris: International Coordination Secretariat for Literacy

UNESCO. 2005 Education for All: Literacy for Life. Paris: UNESCO

OECD. 2013a. PISA 2012 Results: What Student Know and Can Do. Student Performance in Reading, Mathematics and Science Volume I, III, IV. Paris: OECD Publishing.

OECD. 2013b. PISA 2012 Assessment and Analytical Framework: Mathematics, Reading, Science, Problem Solving and Financial Literacy. Paris: PISA-OECD Publishing.

OECD. 2016. PISA 2015 Assessment and Analytical Framework: Science, Reading, Mathematic and Financial Literacy. Paris: PISA-OECD Publishing.

Ojose, B. 2011. "Mathematics Literacy: Are We Able to Put the Mathematics We Learn into Everyday Use?". Journal of Mathematics Education. Vol 4 (1): pp 89-100.

Steen et al. 2007. Developing Mathematical Literacy 